\title{
Some aspects of chloroplast movement in leaves of terrestrial plants
}

\author{
Z. LELAุTKO
}

\section{INTRODUCTION}

Displacement of chloroplasts in numerous plant cells depends mainly on light intensity. Thus, changes in the chloroplast position are the mechanism responsible for the adaptation of the plant to environmental conditions (S e n n, 1908). The dynamics of chloroplast movements has been elaborated for plants with thin leaves consisting of one to three cell layers. From immediate microscopic observations and counts of chloroplasts changing position it was possible to determine this process numerically (V o erke 1, 1934; Z u r y c k a and Z u r y c ki, 1950, 1951, 1953; Zurzycka, 1951).

Displacement of chloroplasts in plants of leaves with multilayered structure was established by Böhm (1856), S t a h 1 (1880), H a berl a nd t (1886) and Senn (1908).

Determination of the dynamics of chloroplast displacement, however, for this group of plants, by means of immediate microscopic observation did not find any wider application. Only $Ł$ o m a i n and co-workers $(1966,1967)$ applied this method after a previous infiltration of the leaf with water for determination of changes in the arrangement of chloroplasts in the spongy parenchyma layer next to the lower epidermis.

It is possible to follow this dynamics of movement in some species e.g. in Arabis arenosa, by separating the spongy parenchyma from the palisade parenchyma and placing this specimen in an isotonic sucrose solution ( $\mathrm{Zurzycki}$ 1955). Establishment of the changes occurring in all cell layers of the leaf by either of the above named methods was impossible.

It is why the method of light transmittance measurement was applied in this paper for measurement of chloroplast movement dynamics. A profile position of the chloroplasts under the influence of strong sunlight causes a decrease in the amount of absorbed light energy. It was already shown in Stahl's experiments $(1880,1909)$ consisting in exposure of a part of a leaf to direct action of light with a simultanous screening of the other parts. Such a leaf gives on a contact print on photosensitive paper darker areas in places where the leaf was irradiated with intensive 
light. This is proof of an increased transmittance in these parts of the leaf of rays active in the photosynthetic process.

$\mathrm{St}$ a h l's method is not a quantitative one, and application of appropriate light detectors is necessary to determine quantitative changes and the spectral character of the transmitted light. The first quantitative estimation of transmittance was given by Det lefs on (1888) for Humulus lupulus in which transmittance increased by $12 \%$ during 37 minutes of illumination. Further investigations were performed both in the line of a detailed character of quantitative changes of transmittance conditioned by displacement of chloroplasts (S e y b o ld, 1955, 1956; Schander ] and $\mathrm{Ka}$ e mpfert, 1933; Z urzycki, 1961) and in the line of establishing changes in reaction of individual species to light intensity (B i e b l, 1954, 1955; B a buskin, 1955 b). Changes in light transmission were found to occur in correlation with changes of chloroplast arrangement (Biebl, 1954; Zurzycki, 1961; Eomagin and co-workers, 1966, 1967).

The first full characteristic of the spectral changes in transmittance was given by S e b old (1955) for Begonia multiflora. He established that changes in the whole spectrum were small and almost independent of the wave length. Z u r z y c k i (1961) found in leaves of Lemna trisulca wide changes in transmittance dependent on wave length, this relation is conditioned by the anatomical structure of the leaf. It results from the experiments of S t a h l (1909), S chanderl and K a e m p fert (1933), B i e bl (1954, 1955), B a buskin (1955 b), Eom a in and co-workers $(1966,1967)$ that higher plants are sensitive to the light stimulus in various degrees dependent on the species as well as developmental conditions of the plant. The hitherto published results concerning a multilayerd leaf do not permit any uniform conclusions as to the influence of chloroplast arrangement on light transmittance ( $\mathrm{Sch}$ anderl and $\mathrm{K}$ a e mp f e r t 1933, B i e b l 1955). Establishment of the exact optical characteristic of the leaf, and changes of optical properties in dependence on light conditions are of great importance for many physiological problems such as photosynthesis, photodestruction of the photosynthetic apparatus etc.

The present paper was aimed at finding answers to two problems:

1. in what way does light transmittance change in the visible spectral range in various species of terrestrial plants;

2. what is the influence of various light intensities and of the period of exposure to light on transmittance.

\section{MATERIAL AND METHODS}

The experimental material consisted of well developed leaves of the following species: Ajuga reptans, Fagus Catalpa sp., Melandrium album, Sedum maximum, Sambucus nigra, 
Symphytum officinale, Tanacetum vulgare, Solanum tuberosum, Vicia faba, Vitis vinifera and Rhus typhina.

Leaves for experiments were taken from natural habitats. Before the experiment was started the material was kept for about 12 hours in a humid chamber in very weak dispersed light of about 20 lux. In order to characterize qualitatively the degree of leaf reaction to the light intensity applied Stahl's (1909) experiments were repeated. A leaf partly screened with black paper was put on moistened filter paper in a Petri dish. The dish was placed on a water jacket coat. The temperature of the system was $25^{\circ} \mathrm{C}$. Experiments were carried out under immediate

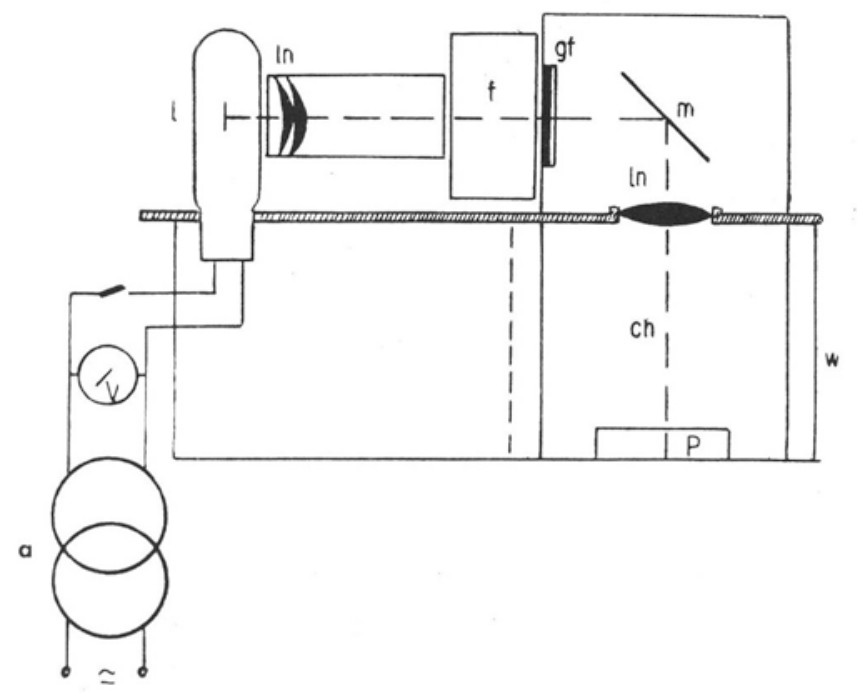

Fig. 1. Scheme of apparatus for irradiation.

$l$ - lamp, $l n$ - lenses, $f$ - filter with $\mathrm{CuSO}_{4}$ solution, $g f-$ glass filter, $m-$ mirror, ch - chamber for illuminations, $P-$ Petri dish, $v-$ voltameter, $a-$ autotransformer, $w$ - water jacket.

sunlight with the use of a KG-1 $(5 \mathrm{~mm})$ filter. The intensity of the incident light was 30-40 klux. The leaf was transferred to darkness after 1 hour of irradiation and a contact print of the leaf was made on photosensitive paper.

In further experiments leaves were illuminated in an apparatus for irradiation. The scheme of this apparatus is presented in figure 1. A Tungsram bulb $220 \mathrm{~V} 500 \mathrm{~W}$ supplied the light. The light was concentrated by means of an optical system and an evenly illuminated spot $2 \mathrm{~cm}$ in diameter was obtained. A glass filter and a liquid filter with $\mathrm{CuSO}_{4}$ were inserted into the optical system. The filters were chosen so as to obtain the colour temperature of about $6000^{\circ} \mathrm{K}$. Light intensity was regulated by means of neutral filters. The light-proof cham- 
ber was surrounded with a water jacket which maintained a constant temperature of $25^{\circ} \mathrm{C}$. During irradiation the leaf was placed on moistened filter paper on a Petri dish.

Quantitative transmittance measurements were performed by applying an opalescent glass (S hib a ta, 1958). The applied measurement set up is presented in figure 2. A microscopic lamp supplied by a stabilizer and autotransformer constituted the light source. Light intensity was regulated by changing the supply voltage by means of an autotransformer. The light emitted by this lamp passed through an appropriate interference filter. IL (Zeiss) filters with maximum transmittance from $375 \mathrm{~nm}$ to $727 \mathrm{~nm}$ were applied at half width $6-8 \mathrm{~nm}$. The leaf was placed on a mo-

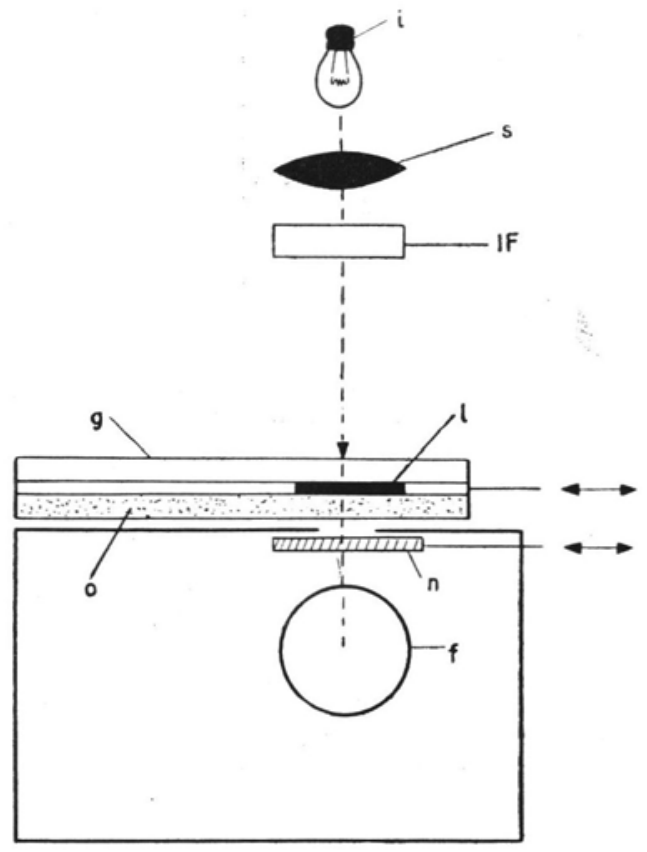

Fig. 2. Scheme of apparatus for light measurements.

$i$ - microscopic lamp, $s$ - lens, IF interference filter, $g-$ normal glass,

$l$ - leaf, o - opalescent glass, $n$ neutral filter, $f$ - photomultiplier.

vable opalescent glass and covered with a normal cover glass to keep the material unmovable and spread flat. The movable opalescent glass made it possible to shift it always to the same position. The measurement surface was limited to a surface area of $8 \times 2 \mathrm{~mm}$ what permitted measurement in a part of the leaf without any larger nerves. A net filter of $12 \%$ transmittance was placed under the opalescent glass; it could be easily excluded from the light course. A photomultiplier RCA-IP 21 supplied with stabilized voltage of $700-1500 \mathrm{~V}$ acted as light detector. The current of the photomultiplier was measured by means of a Kipp and Zonnen galvanometer type A-70. Intensity of the incident light (opalescent glass) was always measured with a neutral filter applied. The plate with the leaf was subsequently shifted. Measurement of the light transmitted 
through the leaf (opalescent glass + leaf) was performed with the neutral filter removed. Such a measurement system permitted readings with an accuracy up to $0,06 \%$ transmittance. Results were calculated as transmittance percentage:

$$
\mathrm{T} \%=\frac{\mathrm{I}_{\mathrm{p}}+\mathrm{I}_{\mathrm{d}}}{\mathrm{I}_{\mathrm{o}}} \cdot 100
$$

or in the form of

semi integral attenuance $=\log \frac{I_{o}}{I_{p}+I_{d}}(S$ h i b a t a 1958) where:

$\mathrm{I}_{0}$ - intensity of the incident light

$\mathrm{I}_{\mathrm{p}}+\mathrm{I}_{\mathrm{d}}$ - intensity of transmitted light

$I_{p}$ - intensity of specular transmittance

$I_{d}$ - intensity of light dispersed in various directions.

Every transmittance value given is the mean of five measurements. At the beginning, transmittance of a series of leaves of the examined species adapted in weak light was measured and mean values were calculated for the given species. Leaves of a medium initial transmission were used for further experiments. Measurements were performed on the same spot of the leaf before, during and after illumination. Spectral changes of transmission were established by use of 21 interference filters. Performance of measurements lasted 5 minutes. Changes in transmittance occurring during this time were negligible. The course of transmittance changes in time was measured by interrupting illumination of the leaf for 1 minute at 20 minute intervals and in this time measurements were performed.

\section{RESULTS}

The experiments (S t a h l's method) allowed to distinguish 3 groups of plants in respect to their reaction. The degree of blacken of the photosensitive paper and changes in the leaf colour after 1 hour of illumination was the adopted criterion of differentiation.

Group I

Leaves of species belonging to this group gave a very intensive reaction of the photosensitive paper in the illuminated places of the leaf (Fig. 3a, c) and a marked change of colour to bright green of the irradiated parts of the leaf itself (Fig. 3b, d). This contrast in pigmentation of the irradiated and screened part of the leaf was reversible and disappeared completly after $1-1,5$ hours. This reaction was observed in the following species: Ajuga reptans, Galeopsis tetrahit, Melandrium album, Sedum maximum, Sambucus nigra, Symphytum officinale. 

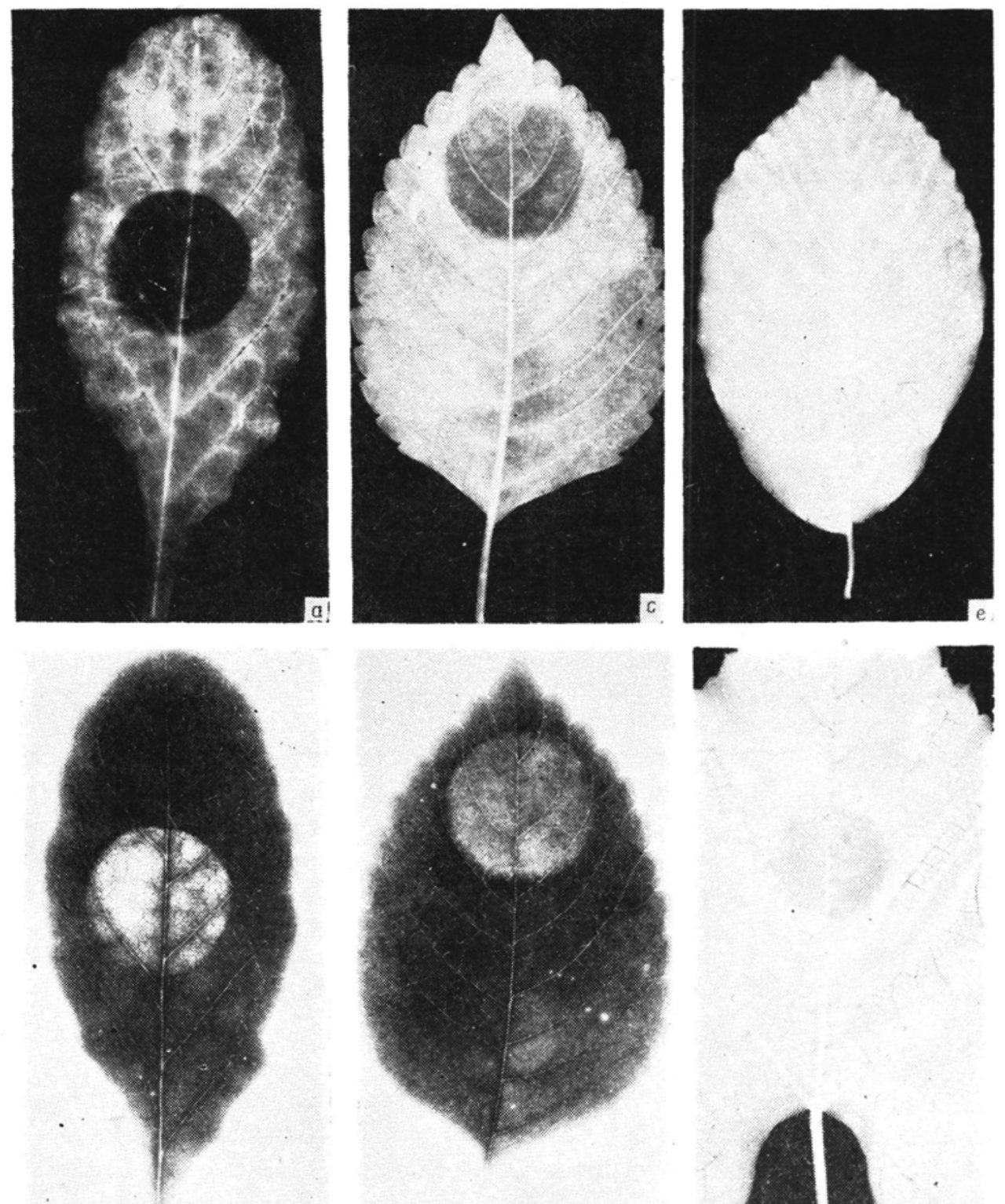

b

\section{d}

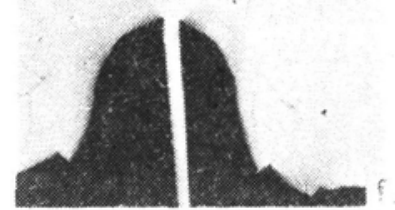

Fig. 3. Contact print of a leaf on photosensitive paper and changes in leaf pigmentation after 1-hour irradiation with light of 131 thousands $\mathrm{erg} / \mathrm{cm}^{2} \mathrm{~s}$ intensity.

$a$ - print of the Ajuga reptans leaf; $b$ - photograph of the same leaf; $c$ - print of Galeopsis tetrahit leaf; $d$ - photograph of the same leaf; $e-$ print of Vitis vinifera leaf; $f-$ print of Fagus silvatica leaf

Fig. 4. Spectral changes in transmittance after 1-hour of exposure to white light of 131 thousands $\mathrm{erg} / \mathrm{cm}^{2} \mathrm{~s}$.

- O- leaf transmittance in weak light; - - O--O-- leaf transmittance after irradiation a - Ajuga reptans; b - Galeopsis tetrahit; c - Vitis vinifera; d - Fagus silvatica; e - Rhus typhina; $\mathrm{f}-$ Vicia faba 
Chloroplast movement in leaves

459
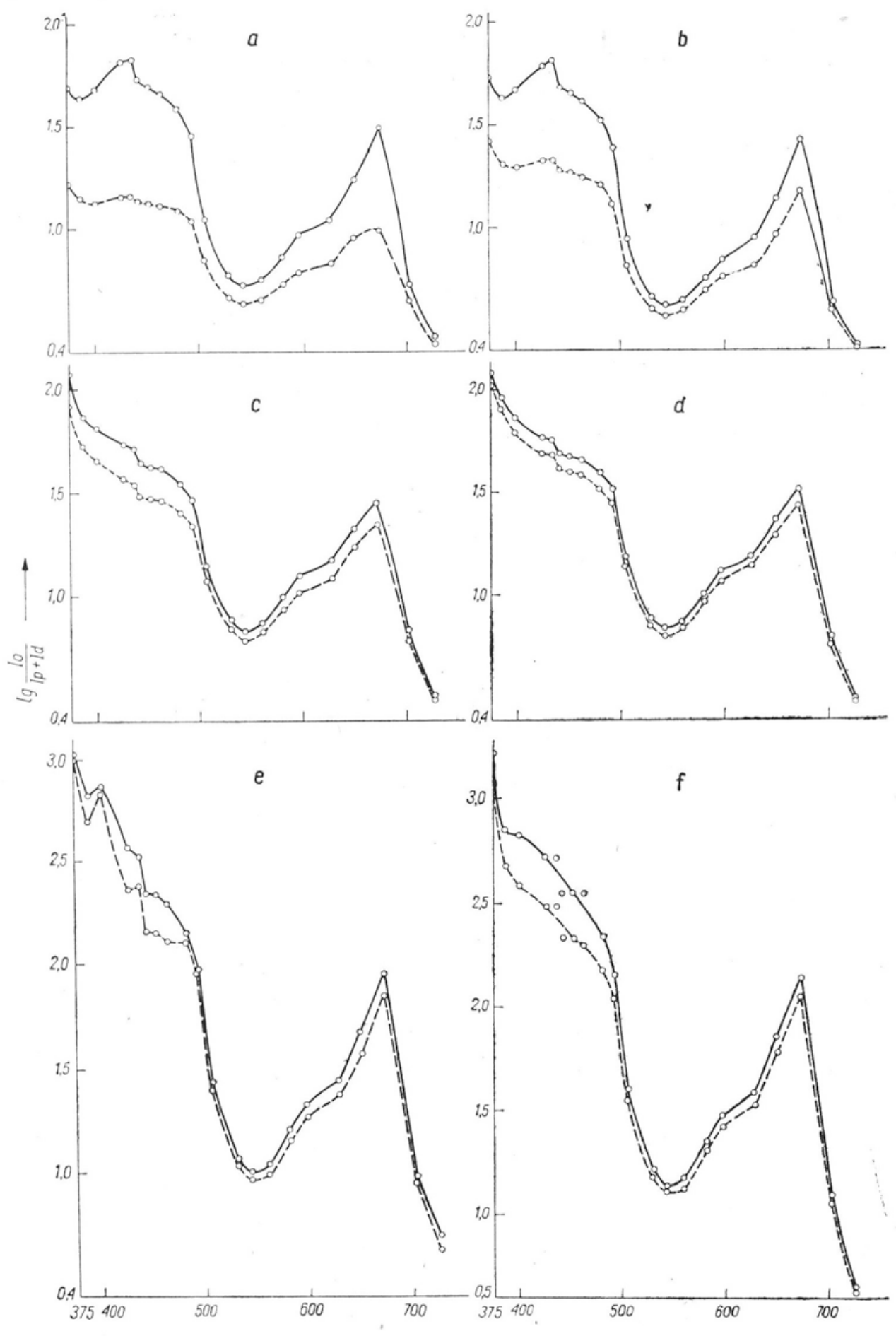

$$
\mathrm{nm} \longrightarrow
$$

Fig. 4 
Table 1

Changes in light transmission for $\lambda=436 \mathrm{~nm}$ after irradiation with white light of 131 thousands $\mathrm{erg} / \mathrm{cm}^{2} \mathrm{~s}$ intensity

\begin{tabular}{l|c|c|c}
\hline \multicolumn{1}{|c|}{ Object } & $\begin{array}{c}\text { Transmission } \\
\text { of leaf adapted } \\
\text { in weak light } \\
\%\end{array}$ & $\begin{array}{c}\text { Transmission } \\
\text { after 1-hour } \\
\text { irradiation } \\
\%\end{array}$ & $\Delta \%$ \\
\hline a) species I group & & & \\
Ajuga reptans & 1,50 & 6,93 & 5,47 \\
Galeopsis tetrahit & 1,58 & 4,69 & 3,11 \\
b) species II group & & & \\
Vitis vinifera & 1,92 & 2,82 & 0,90 \\
Fagus silvatica & 1,75 & 2,08 & 0,33 \\
c) species III group & 0,19 & & \\
Vicia faba & 0,30 & 0,33 & 0,14 \\
Rhus typhina & & 0,46 & 0,16 \\
\hline
\end{tabular}

Group II

Species in this group showed a weaker blacking of the photo-sensitive paper on the contact print in the places where the leaf was exposed to light; the change in colour between the illuminated and unilluminated part of the leaf was only slightly visible. Vitis vinifera and Fagus silvatica (fig. 3 e, f) belong to this group.

\section{Group III}

In this group of plants no changes were detected by means of $\mathrm{S} t \mathrm{t}$ h l's method. The following species belong here: Vicia faba, Solanum tuberosum, Rhus typhina, Tanacetum vulgare and Catalpa sp. Two species from each group were chosen for further investigations.

Spectral changes of transmittance after 1 hour of irradiation with white light of 131 thousands $\mathrm{erg} / \mathrm{cm}^{2} \mathrm{~S}$ intensity are shown in figure $4 \mathrm{a}-\mathrm{f}$. In species reacting strongest i.e. in Ajuga reptans and Galeopsis tetrahit very distinct spectral changes were observed. Most intensive transmittan-

Table 2

Changes in light transmittance in the range $375-727 \mathrm{~nm}$ after irradiation with white light of 131 thousands $\mathrm{erg} / \mathrm{cm}^{2} \mathrm{~s}$ intensity

\begin{tabular}{l|c|c|c}
\hline Object & $\begin{array}{c}\text { Transmission } \\
\text { of leaf adapted } \\
\text { in weak light } \\
\%\end{array}$ & $\begin{array}{c}\text { Transmission } \\
\text { after 1-hour } \\
\text { irradiation } \\
\%\end{array}$ & $\Delta \%$ \\
\hline Ajuga reptans & $\%, 30$ & 14,20 & 4,90 \\
Galeopsis tetrahit & 11,50 & 14,60 & 3,10 \\
\hline
\end{tabular}




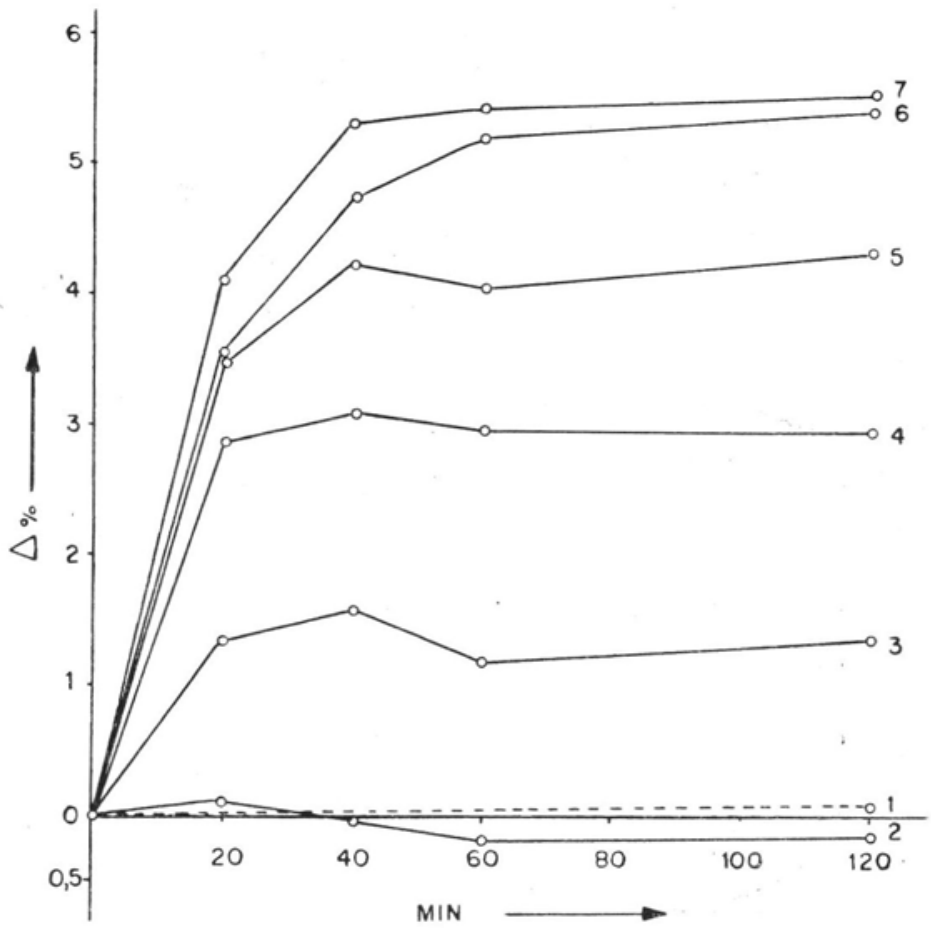

Fig. 5. Changes in light transmittance of $436 \mathrm{~nm}$ wave length in leaves of Ajuga reptans under the influence of various light intensities.

curves: $1-0 \mathrm{erg} / \mathrm{cm}^{2} \mathrm{~S} ; 2-4000 \mathrm{erg} / \mathrm{cm}^{2} \mathrm{~s} ; 3-9000 \mathrm{erg} / \mathrm{cm}^{2} \mathrm{~s} ; 4-18600 \mathrm{erg} / \mathrm{cm}^{2} \mathrm{~S} ; 5-36000$ $\mathrm{erg} / \mathrm{cm}^{2} \mathrm{~s} ; 6-65000 \mathrm{erg} / \mathrm{cm}^{2} \mathrm{~s} ; 7-253000 \mathrm{erg} / \mathrm{cm}^{2} \mathrm{~s}$

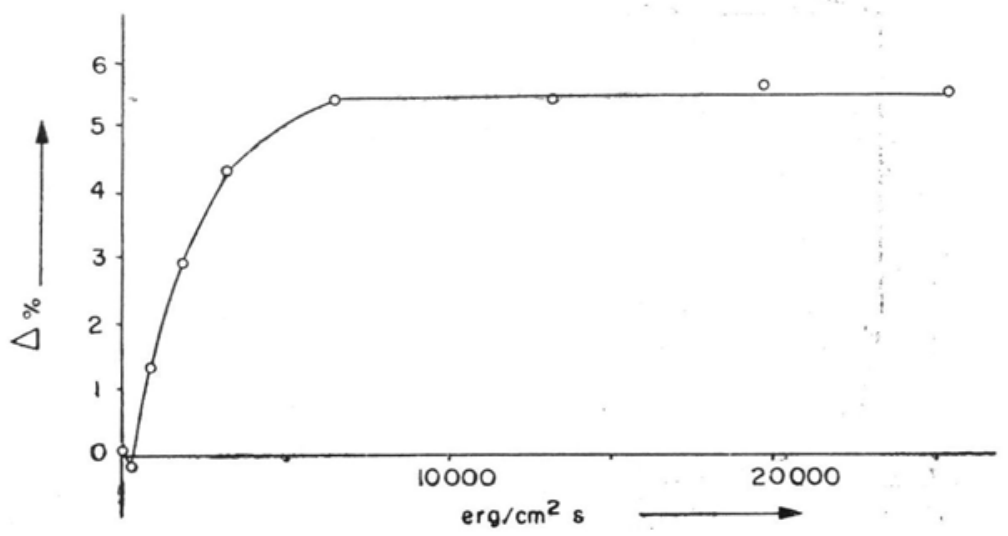

Fig. 6. Percentual changes of transmittance in leaf of Ajuga reptans measured at $\lambda=436 \mathrm{~nm}$ when stabilization was reached after irradiation with white light of various intensity (axis $\mathrm{x}$ ). 


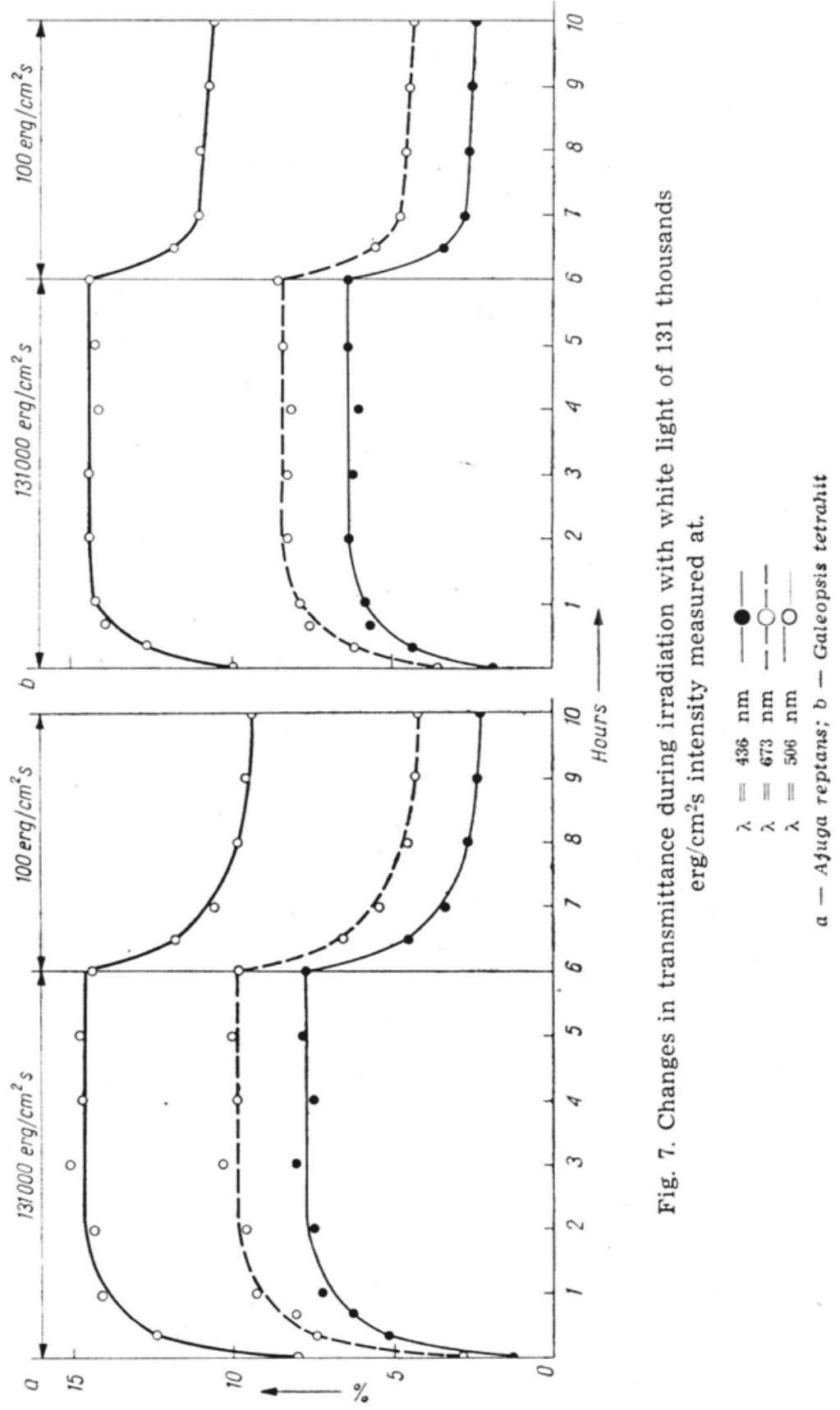


ce occurred in these species in the short-wave spectrum range below 481 $\mathrm{nm}$, and a weaker increase between $597 \mathrm{~nm}-680 \mathrm{~nm}$. The range between $481 \mathrm{~nm}-597 \mathrm{~nm}$ and above $680 \mathrm{~nm}$ gives only slight changes in transmittance.

As it results from the data presented the main increase in transmission was observed in the range of high absorption of photosynthetic pigments. In Vitis vinifera and Fagus silvatica spectral changes in transmission were considerably smaller. The increase of transmission was almost equal in the whole spectral range with the exception of the short wave range where differences were more pronounced.

In Rhus typhina and Vicia faba changes of transmission were correlated with the results obtained by means of Stahl's method. In view of the fact that photosensitive paper reacts in the blue-violet range, changes of transmission in this range are responsible for the degree of blacking. Table 1 shows the changes in transmission expressed in percents for $\lambda=436 \mathrm{~nm}$. Transmission changes in the leaves of intensively reacting species in the whole visible range expressed as percentage were calculated with the use of a planimeter diagrams and are presented in table 2 . Experiments on the influence of various light intensities indicate a pronounced dependence of this process on the intensities applied (Fig. 5). The highest increase in transmittance was observed within the first 20 minutes of exposure to light; it slowed down subsequently within 2 hours. Further exposure to light was uneffective for the increase of transmittance (Fig. $7 \mathrm{a}, \mathrm{b})$. Changes in transmittance after reaching equilibrium are shown in Fig. 6. It results from these data that light intensity of the order of 65 thousands erg $/ \mathrm{cm}^{2} \mathrm{~s}$ causes a maximal increase of transmittance. A rise of light intensity to 253 thousands erg $/ \mathrm{cm}^{2} \mathrm{~s}$ does not induce any further changes. Transmittance changes are reversible. A leaf submitted to the action of very intensive light for 6 hours shows a considerable drop in transmittance after the first 30 minutes, when transferred to weak light. The further decrease in transmittance proceeds at a much lower rate and after 4 hours it attains a value approaching the initial one (Fig. 7 a, b). Exposure to white light and transmittance examined for $\lambda=436$ $\mathrm{nm}, \lambda=506 \mathrm{~nm}$ and $\lambda=673 \mathrm{~nm}$ have identical course in time.

As it results from the diagrams the time necessary for stabilization at exposure to weak light is twice as long as that necessary for intensive light.

\section{DISCUSSION}

It has been found many times that a series of optical properties of leaves - above all light transmittance and reflexion - change according to the light conditions acting on the leaf. These changes are reversible ( $\mathrm{t}$ t a h l, 1909; Bi e b l, 1954, 1955; Z u r z y cki, 1961). Measurements of 
transmittance changes made when applying white light and spectrally selective detectors do not permit determination of the magnitude of these changes exactly, and give only rough data (B i e b l, 1954, 1955; $\mathrm{B}$ a buskin, 1955 a). Measurements made in monachromatic light in the whole range of the spectrum should constitute the basis for characterizing the optical changes in the leaf precisely. As there exist only few papers containing such data (S e y bold, 1956; Z urzycki, 1961) an attempt was made to collect in the present paper more extensive material concerning transmittance changes.

The results obtained are in agreement with the previously published ones. It has been established that some groups of plants can be differentiated in respect to their different transmittance reaction to applied light. Biebl (1955) distinguishes also, on the basis of field investigations, a number of plant types reacting in a different way to daily changes in illumination.

Quantitative changes in transmittance established in the present paper are of a similar order of magnitude as those given by other authors:

$\begin{array}{ll}\text { Ajuga reptans } & 2,3 \%-5,5 \% \\ \text { Galeopsis tetrahit } & 0,8 \%-4,1 \% \\ \text { Vicia faba } & 0,3 \%-0,77 \% \\ \text { Begonia multiflora } & 3 \%-5 \% \text { (S e y bold, 1956) } \\ \text { Lemna trisulca } & 3 \%-12 \% \text { (Z u r y c k i, 1961) }\end{array}$

In the present investigations, changes in reflexion were not measured. The fact of strict correlation between these changes and transmittance changes as well as a comparison with other investigated objects (S e ybold, 1933, 1956) permits rough estimation of the entire absorption change in a leaf of Ajuga reptans at about $6 \%$ and of Galeopsis tetrahit at about $5 \%$; in less sensitive plants it is much lower. These values are very close to those given by $\mathrm{S}$ e y bold (1956) and indicate that light absorption changes which result from this reaction are small even in plants which are highly photosensitive.

The changes in leaf properties are explained as the result of changes in the chloroplast arrangement. (D et le f s o n, 1888; Stah 1, 1909; Sch anderl and K a e m pfert, 1933; B i e b l 1954, Z urz y cki, 1961, Ło magin and co-workers 1966, 1967) or as a result of other changes occurring in the leaf cells, e.g. destruction of photosynthetic pigments, accumulation of starch and changes in the internal geometry of the leaf due to loss of water ( $\mathrm{S} \mathrm{ch}$ anderl and $\mathrm{K}$ a e m pfert, 1933; B i e b l, 1955). A correlation of the results obtained by means of the light transmittance measurement method with a microscopic picture of the cell (B i ebl, 1954; Z urzycki 1961; Eomag in and co-workers, 1966, 1967) speaks for the changes of chloroplast arrangement being the cause of changes of optical properties. A comparison of the kinetics of trans- 
mittance changes made by Bie bl (1954) in a leaf of Begonia hydrocotyliofolia and chloroplast displacements in Lemna trisulca described by Z urzycki and Z u z y cka (1953) point to a far going synchronisation of both these phenomena. Absence of any changes in transmitance in plants the chloroplasts of which have no displacement ability, e.g. Fontinalis antipiretica, Juglans regia ( $\mathrm{Z} \mathrm{urzy} \mathrm{c} \mathrm{ki,} \mathrm{1961;} \mathrm{Ło} \mathrm{m} \mathrm{a} \mathrm{in} \mathrm{and} \mathrm{co-}$ -workers, 1966, 1967) is another argument supporting the theory that transmittance changes are caused by chloroplast displacements.

The destruction of pigments might be also considered in view of the fact that changes in leaf decolouration and increased transmittance are most intensive in skiophilous plants, that is in those which have a most sensitive photosynthetic apparatus. Measurements of spectral changes in transmittance show that these changes occur most commonly in the short-wave range and in red light; this is connected with a decreased absorption in photosynthetic pigments. Montfort (1941) and Munding (1952) established in their investigations that the decomposition process of pigments resulting in a decolouration of the tissue can proceed in a living cell under intensive light. Decomposition of pigments is preceeded by a lag phase; during this phase intensive light does not cause any changes in the concentration of pigments. The phase of proper photooxidation, covers a longer period of time and leads to a rapid decomposition of pigments (Sironval and Kandler, 1958; Zurzycki, 1964). Only in dead cells is no lag phase is observed ( $\mathrm{Sir}$ onval and $\mathrm{K}$ a n dler, 1958). Exposure of leaves of Ajuga reptans and Galeopsis tetrahit to intensive light caused an immediate increase of transmittance which after stabilization remained at a low level. The reversibility of the changes observed consisting in reaching previous transmission values within $2-3$ hours of exposure to weak light speaks against explaining the observed transmission changes by decomposition of photosynthetic pigments.

The changes in internal geometry occurring in the leaf owing to a loss of water and starch accumulation can be of some importance under natural conditions of a several hours long irradiation with sunlight when the water deficit may be high (B i e b l, 1955).

A state of equilibrium lasting for a longer period of exposure to light as well as reversibility of the occurring changes in weak dispersed light were observed in our experiments. These findings permitted the conclusion that the transmittance changes are connected with chloroplast displacements. It has been established by S t a h l's method and measurement of light transmittance that in a number of species the increase in leaf transmittance was low or practically none. As this concerns sun plants there arises the question whether the light intensities applied were not too low.

It results from many authors' experiments that the degree of sensitivity of chloroplasts to the light stimulus can vary widely (S t a h 1, 1909; 
$\mathrm{S} \mathrm{ch}$ a $\mathrm{nde}$ r l and $\mathrm{K}$ a e $\mathrm{mp}$ f er t, 1933; B i e b 1 1954, 1955; Z u r z y c ki, 1961; B a b u ski n, 1955 b; Ło m a g in and co-workers, 1966, 1967). Even within one species great differences can occur in the reaction to the light stimulus. This is due by ontogenetic adaptation to the light conditions of the habitat (B a buskin, 1955 b). In our experiments some species did not react to this stimulus even after immediate exposure to sunlight. It may therefore, be assumed that in natural conditions the leaves of plants examined do not show any transmittance changes. A weak reaction or its lack in some species is not caused by the intensity of the applied light but it is a specific feature of a given species, on one hand, and an adaptation to ecological conditions, on the other.

\section{SUMMARY}

Changes in transmittance of radiation through a leaf caused by various light intensities were examined under controlled conditions.

Great differences in the reaction extent to illumination were established in various species by $\mathrm{S}$ ta hl's contact print method.

In most intensively reacting species e.g. Ajuga reptans the maximum increase in transmittance varies within the limits $2,3-5,5 \%$ (in dependence on the wave length). The decrease in light absorption can be estimated under the above given conditions at about $6 \%$.

In a certain range of light intensity, transmittance changes were found to depend on this intensity. Stabilization after illumination with strong light is reached after about $1-2$ hours, with weak light - after $2-3$ hours.

The transmittance changes observed are caused under the experimental conditions by a displacement of chloroplasts in the cells.

I am deeply indebted to Professor J. Zurzycki, Head of the Department of Plant Physiology, Jagiellonian University for his valuable advice and interest in the work.

Department of Plant Physiology,

Jagiellonian University,

Cracow, Grodzka 53

(Entered: February 11, 1970)

\section{REFERENCES}

B a b u skin L. N., 1955 a, Spektr fototaksisa chloroplastow, DAN SSSSR, 103: 333-5. B a bu skin L. N., 1955 b, Adaptacija aparata fototaksisa chloroplastow k intensiwnosti swieta, DAN SSSR, 102: 1215-1218.

B i e bl R., 1954, Lichttransmission und Chloroplastenbewegung, Flora 141: 163-177.

Bi ebl R., 1955, Tägesgänge der Lichttransmission verschiedener Blättern, Flora 142: $290-294$.

B ö h m J. A., 1856, Beiträge zur näheren Kenntnis des Chlorophylls, Sitzgsber. Akad. Wiss. Wien, Math.-naturwiss. K1. 22: 479-512. 
Det 1 efs o n E., 1888, Die Lichtabsorption in assimilierenden Blättern, Arb. Bot. Inst. Würzburg 3: 534 .

$\mathrm{H}$ a berlandt G., 1886, Utber das Assimilationsystem, Ber. 'd. Deutch. Bot. Ges. 4: 206.

Eomagin A. G., Antropowa T. A., Semenichina L. V., 1966, Phototaxis of chloroplast as a cryterion of viability of leaf parenchyma, Planta 71: 119-124.

Łomagin A. G., Antropowa T. A., Semenichina L. V., 1967, Opredelenie żizniesposobnosti parenchymy lista po fototaksisu chloroplastow, Fizj. Rast. 14: $1071 \longrightarrow 1079$.

M o n t f ort C., 1941, Lichtlähmung und Lichtbleichung bei Wasserpflanzen. Grundsätzliches zur physiologischen Gestalt der submersen Blütenpflanzen, Planta 32: 121.

M un ding H., 1952, Untersuchungen zur Frage der Strahlenresistenz des Chlorophylls in den Chloroplasten, Protopl. 41: 212-234.

$\mathrm{Sch}$ a n d e r l and K a e m p fert W., 1933, Ưber Strahlungdurchlässigkeit von Blätter und Blattgeweben, Planta 18:700-750.

S e n n G., 1908, Die Gestalts - und Lageveränderung der Fflanzen chromatophoren, Engelmann, Leipzig.

S e y bold A., 1933, Uber die Optischen Eigenschaften der Laubblätter. III, Planta 20:557-601.

S e y bold A., 1955, Beitrage zur Optik der Laubblätter, Beitr. Biol. Pfl. 31:499-513.

Se ybold A., 1956, Hat die Chloroplastenverlagerung in Laubblätter eine Bedeutung? Naturwiss. 43:90-91.

Shiba t a C., 1958, Spectrophotometry of intact biological materials, Jour. of Biochem. 45:599-623.

Sironval C., Kandler O., 1958, Photooxydation processes in normal green Chlorella cells. I. The bleaching process, Bioch. Biophys. Acta 29:359-368.

$\mathrm{Stahl} \mathrm{E.,} \mathrm{1880,} \mathrm{Ưber} \mathrm{den} \mathrm{Einfluss} \mathrm{von} \mathrm{Richtung} \mathrm{und} \mathrm{Stärke} \mathrm{der} \mathrm{Beleuchtung} \mathrm{auf}$ einige Bewegungserscheinungen im Pflanzenreiche, Bot. Ztg. 38:229.

St a h 1 E., 1909, Zur biologie des Chlorophylls, Jena.

Voerkel S. H., 1934, Untersuchungen über die Phototaxis der Chloroplasten, Planta $s 1: 156-205$.

Z urzycka A., 1951, The influence of the wave length of light on the movements of chloroplasts in Lemna trisulca L., Acta Soc. Bot. Pol. 22:17-37.

Z urzyckaA. and Zurzycki J., 1951, The influence of temperature on phototactic movements of chloroplasts, Acta Soc. Bot. Pol. 20:665-680.

Zurzycki J. and Zurzycka A., 1951, Investigation onto phototactic movements of chloroplasts in Selaginella Martensii Spring., Bull. Acad. Sc. Cracovie B. I. $235-251$.

Z urzycka A. and Zurzycki J., 1953, Studies on the phototactic movements of chloroplasts. I, Acta Soc. Bot. Pol. 22:667-678.

Zurzycki J., 1955, A new object for investigation on the phototactic chloroplast movements, Acta Soc. Bot. Fol. 24:417-419.

Zurzycki J., 1961, The influence of chloroplast displacements on the optical properties of leaves, Acta Soc. Bot. Pol. 30:503-527.

Zurzycki J., 1964, Photooxydative bleaching of chlorophyll pigments in vivo caused by chromatic radiation, Acta Soc. Bot. Pol. 33:121-132. 


\section{Pewne aspekty ruchu chloroplastów w liściach roślin lądowych}

\section{STRESZCZENIE}

Badano zmiany transmisji promieniowania przez liście, wywołane różnym oświetleniem liści w kontrolowanych warunkach.

Stosując metodę contact print Stahla stwierdzono znaczne różnice w stopniu reagowania na silne oświetlenie u różnych gatunków.

U gatunków najsilniej reagujących np. Ajuga reptans maksymalny wzrost transmisji waha się $\mathrm{w}$ granicach od 2,3 do $5,5^{\%} \%$ (w zależności od długości fali). Zmniejszenie absorpcji światła w powyższych warunkach można szacować na około $6 \%$.

Stwierdzone zmiany transmisji są w pewnym zakresie intensywności światła zależne od tej intensywności. Osiągnięcie stanu równowagi po oświetleniu silnym światłem następuje po około $1-2$ godzin, w świetle słabym po około $2-3$ godzin.

Obserwowane zmiany transmisji są w warunkach stosowanych w doświadczeniach spowodowane przemieszczeniami chloroplastów w komórkach. 